Wordsworth: A Poet's History 
Also by Keith Hanley

AN ANNOTATED CRITICAL BIBLIOGRAPHY OF WILLIAM WORDSWORTH GEORGE MEREDITH: Selected Poems (editor)

REVOLUTION AND ENGLISH ROMANTICISM: Politics and Rhetoric (co-editor) ROMANTIC REVISIONS (co-editor) WALTER SAVAGE LANDOR (editor) 


\section{Wordsworth: A Poet's History}

Keith Hanley

Professor of English Literature

Lancaster University 


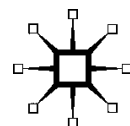

只

(C) Keith Hanley 2001

Softcover reprint of the hardcover 1st edition 2001 978-0-333-91883-8

All rights reserved. No reproduction, copy or transmission of this publication may be made without written permission.

No paragraph of this publication may be reproduced, copied or transmitted save with written permission or in accordance with the provisions of the Copyright, Designs and Patents Act 1988, or under the terms of any licence permitting limited copying issued by the Copyright Licensing Agency, 90 Tottenham Court Road, London W1P OLP.

Any person who does any unauthorised act in relation to this publication may be liable to criminal prosecution and civil claims for damages.

The author has asserted his right to be identified as the author of this work in accordance with the Copyright, Designs and Patents Act 1988.

First published 2001 by

PALGRAVE

Houndmills, Basingstoke, Hampshire RG21 6XS and 175 Fifth Avenue, New York, N. Y. 10010

Companies and representatives throughout the world

PALGRAVE is the new global academic imprint of

St. Martin's Press LLC Scholarly and Reference Division and Palgrave Publishers Ltd (formerly Macmillan Press Ltd).

ISBN 978-1-349-42378-1 ISBN 978-0-230-28813-3 (eBook)

DOI $10.1057 / 9780230288133$

This book is printed on paper suitable for recycling and made from fully managed and sustained forest sources.

A catalogue record for this book is available from the British Library.

Library of Congress Cataloging-in-Publication Data

Hanley, Keith.

Wordsworth : a poet's history / Keith Hanley.

p. $\mathrm{cm}$.

Includes bibliographical references and index.

1. Wordsworth, William, 1770-1850-Knowledge-History. 2.

Literature and history-Great Britain-History-19th century. 3. France-History-Revolution, 1789-1799-Influence. 4. Wordsworth, William, 1770-1850-Psychology. 5. Poetry-Psychological aspects. 6.

Psychology in literature. 7. Patriotism in literature. 8. History in literature. I. Title.

PR5892.H5 H36 2000

$821 \cdot .7-\mathrm{dc} 21$

$\begin{array}{llllllllll}10 & 9 & 8 & 7 & 6 & 5 & 4 & 3 & 2 & 1\end{array}$

$\begin{array}{llllllllll}10 & 09 & 08 & 07 & 06 & 05 & 04 & 03 & 02 & 01\end{array}$ 
In memory of Emma Hanley 
Relating simply as my wish hath been

A poet's history

Wordsworth, The Prelude

No, life as the eternal continuing of mind and wit does not represent itself to us as a vision of savage greatness and ruthless beauty; we who are set apart and different do not conceive it as, like us, unusual; it is the normal, respectable, and admirable that is the kingdom of our longing: life, in all its seductive banality! That man is far from being an artist, my dear, whose last and deepest enthusiasm is the raffine, the eccentric and satanic; who does not know the longing for the innocent, the simple, and the living, for a little friendship, devotion, familiar human happiness - the gnawing, surreptitious hankering, Lisabeta, for the bliss of the commonplace.

Thomas Mann, Tonio Kröger 


\section{Contents}

List of Illustrations viii

List of Abbreviations $\quad$ ix

Acknowledgements $\quad$ xi

Introduction: The Secret Histories of 'Wordsworth' 1

Secret Agents 1

The Case History: 'Wordsworth' the Poem 12

'Wordsworth' as History 25

The History of 'Wordsworth' 29

1 The Spectral Mother 33

The Woman in White $\quad 33$

'The ghosts of dead mothers' $\quad 45$

Mummies $\quad 53$

2 The Elided Father $\quad 67$

$\begin{array}{ll}\text { The Language of Nature } & 67\end{array}$

$\begin{array}{ll}\text { Dedicated Spirits } & 76\end{array}$

$\begin{array}{ll}\text { Inbetweens } & 95\end{array}$

3 Describing the Revolution 113

$\begin{array}{ll}\text { Squaring the Circle } & 113\end{array}$

$\begin{array}{lr}\text { Arguing in a Circle } & 126\end{array}$

$\begin{array}{ll}\text { Cold Carnival } & 141\end{array}$

4 Changing Spots $\quad 150$

$\begin{array}{ll}\text { Power Poetry } & 150\end{array}$

$\begin{array}{ll}\text { Restoration Drama } & 167\end{array}$

$\begin{array}{ll}\text { Holmes at Grasmere } & 181\end{array}$

5 The Shock of the Old 193

'Poetically electric subjects' 193

$\begin{array}{ll}\text { Shock Therapy } & 202\end{array}$

Wild Grasses $\quad 220$

$\begin{array}{ll}\text { Notes } & 238\end{array}$

$\begin{array}{ll}\text { Works Cited } & 247\end{array}$

$\begin{array}{lr}\text { Index } & 256\end{array}$ 


\section{List of Illustrations}

1 Charles Le Brun, Sainte Madeleine repentante renonce a toutes les vanités de la vie, c.1656-7

(Musée du Louvre)

2 Marie-Guillermine Benoist, Portrait d'une négresse, 1800 (Musée du Louvre)

3 Exhumation of Wickliffe, woodcut from The Acts and Monuments of John Foxe (1563)

4 and 5 The Minstrel and The Hermit, engraved by Richard Westall, 1816. From Poetical Works of James Beattie (1818)

6 B. R. Haydon, Wordsworth on Helvellyn (The Wordsworth Museum, Grasmere; unfinished)

7 James Gillray, Mary of Buttermere: Sketch'd from Life, July, 1800 (The Wordsworth Museum, Grasmere)

8 and 9 Illustrations I and II, 2 Henry IV, engravings of Josiah Boydell's paintings for his Collection of Prints ... Illustrating the Dramatic Works of Shakespeare (1803)

10 Thomas Rowlandson, Filial Piety, 1788 (The British Museum)

11 Jacques Louis David, Sacre de l'Empereur Napoléon Ir et Couronnement de l'Impératrice Joséphine à Notre-Dame le 2 décembre 1804 (Musée du Louvre)

12 'At my Cry He Dropped It', illustration to 'The Beryl Coronet', by Sidney Paget for the Strand Magazine (May 1892). 


\section{List of Abbreviations}

For works referred to throughout

$B L$

Biographia Literaria, ed. James Englell and W. Jackson Bate (1984), vol. 7 of The Collected Works of Samuel Taylor Coleridge, gen. ed. Kathleen Coburn, Bollingen Series LXXV (London and Princeton, 1969- ).

CLL Lectures 1808-1819: On Literature, ed. R. A. Foakes, 2 vols (1987); vol. 5 of the Collected Works of Samuel Taylor Coleridge.

DQ The Complete Works of Thomas De Quincey, 3rd edn, ed. David Masson, 16 vols (Edinburgh, 1862-71).

H The Complete Works of William Hazlitt, ed. P. P. Howe, 21 vols (London, 1930-4).

HCRBW Henry Crabb Robinson on Books and Their Writers, ed. Edith J. Morley, 3 vols (London, 1938).

LSTC Collected Letters of Samuel Taylor Coleridge, ed. Earl Leslie Griggs, 6 vols (Oxford and New York, 1956-71).

Memoirs Christopher Wordsworth, Memoirs of William Wordsworth, 2 vols (London, 1851).

Prel The Prelude: 1799, 1805, 1850, ed. Jonathan Wordsworth, M. H. Abrams and Stephen Gill (New York, 1979).

Prose The Prose Works of William Wordsworth, ed. W. J. B. Owen and Jane Worthington Smyser, 3 vols (Oxford, 1974).

PSTC The Complete Poetical Works of Samuel Taylor Coleridge, ed. Ernest Hartley Coleridge, 2 vols (Oxford, 1912).

PW The Poetical Works of William Wordsworth, ed. Ernest de Selincourt and Helen Darbishire, 5 vols (Oxford, 1940-9).

$S$ Shakespeare's Dramatic Works; with explanatory notes. A new edition, ed. S. Ayscough, 3 vols (Dublin, 1790). The copy of vols I and II, bound together, at the Wordsworth Library, Grasmere.

TT Table Talk, ed. Carl Woodring, 2 vols (London and Princeton, 1990); vol. 14 of The Collected Works of Samuel Taylor Coleridge.

WL The Letters of William and Dorothy Wordsworth, 2nd edn, gen. ed. Alan G. Hill, 8 vols (Oxford, 1967-93), comprising: 
The Early Years, 1787-1805, rev. Chester L. Shaver (1967); The Middle Years, Pt 1: 1806-1811, rev. Mary Moorman (1969); The Middle Years, Pt 2: 1812-20, rev. Mary Moorman and Alan G. Hill (1970); The Later Years, Pt 1: 1821-1828, rev. Alan G. Hill (1978); The Later Years, Pt 2: 1829-1834, rev. Alan G. Hill (1979); The Later Years, Pt 3: 1835-1839, rev. Alan G. Hill (1982); The Later Years, Pt 4: 1840-1853, rev. Alan G. Hill (1988); A Supplement of New Letters, rev. Alan G. Hill (1993). 


\section{Acknowledgements}

Readers of this book may hardly be surprised to learn that it is primarily indebted to my mother. I still hear many passages of English poetry, and especially Wordsworth, which she had by heart, in her rapt voice. Much of the time it has taken I owe to the understanding of my wife, Jadzia, and my children, Timothy and Kitty.

Foremost among those others without whom it could not have been written is Jonathan Wordsworth, not only because of his scholarly and critical example since the days when I attended his unforgettable seminars, assisted by Mary Jacobus, at Oxford, but also for many acts of imaginative generosity over the years. Though he will be anxious not to have influenced my theorizing, I hope he will not disown the contours of a reading that I at least believe in many ways proceeds from his teachings.

When some of the ideas behind this work were gestating through the 1980s, I attended several Wordsworth Summer Schools at Grasmere, where I enjoyed and greatly profited from the company, among others, of Jonathan Bate, Tony Brinkley, Peter Larkin, Tom McFarland, Lucy Newlyn, Nick Roe, Nicky Trott and Duncan Wu. My particular interest in Lacan was deepened by attending the Lacan Seminars organized by the French Department of Manchester University in the mid-1980s, and in the mid-1990s by the discussions I had with John Peacock and Douglas Fraser in the Manchester Centre for Freudian Analysis cartel. My colleagues in the Wordsworth Centre at Lancaster University, Tony Pinkney and Fred Botting, have never failed in their support, and I warmly thank and acknowledge the intellectual stimulus that I gained from the late John Stachniewski and Raman Selden, from Chris Baldick and, most especially, Richard Wilson.

For various acts of help and encouragement I am grateful to the following friends and colleagues: David Carroll, Bill Galperin, Stephen Gill, Roger Holdsworth, Ken Johnston, Greg Kucich, Kevin McLaughlin, Vince Newey, Bernard and Heather O'Donoghue, Peter Swaab, Dick Watson and Michael Wheeler. Jeff Cowton, Librarian of the Wordsworth Library, Grasmere, generously shared his knowledge of Wordsworth's reading with me. Lynne Pearce commented usefully on Chapter 2 and David Carroll on Chapter 5, while Tony Brinkley, whose engagement with my work on Wordsworth has been a long-standing stimulus, has 
read and reacted to the whole manuscript with characteristic warmth and sensitive insight. Yet, for all the above advantages, I alone, of course, am responsible for the present book.

St Deiniol's Library, Hawarden, granted me a Residential Scholarship, partially supported from the Canon Symonds Fund, to pursue my research on the later Wordsworth in 1994. Some ideas that inform the introduction were broached in a guest paper, 'Wordsworth's Revolution in Poetic Language', for the bicentenary issue of Romanticism on the Net, 9, edited by Nicola Trott and Seamus Perry in February 1998; a version of Chapter 1 appeared in the journal News from Nowhere: Theory and Politics of Romanticism, edited by Tony Pinkney, Keith Hanley and Fred Botting (Keele, 1995); some material included in Chapter 2 was delivered in a panel on 'Feminists Reading Wordsworth' organized by Laura Haigwood for the Toronto Modern Language Association convention in 1993 and part was also given in a paper read at the British Association for Romantic Studies conference organized by Viv Jones and John Whale at Leeds in 1997; part of Chapter 3 was published in Wordsworth in Context, a special issue of the Bucknell Review, edited by Pauline Fletcher and John Murphy (Lewisburg, 1992), and is included here with the publisher's permission; some of the ideas from which Chapter 4 developed were shared at a staff seminar I was invited to give in the English Department at Leicester University and were delivered in a paper at the Interdisciplinary Nineteenth-Century Studies conference at the College of William and Mary, Williamsburg, in 1994; and Chapter 5 grew out of lectures I delivered on 'The Electrification of Great Britain' at the invitations of Amitava Roy of the Rabindra Bharati University, Calcutta, and of Martin Zerlang of the Centre for Urbanity and Aesthetics, Copenhagen, in 1995, before they were gathered into a shorter written version published in Mortal Pages, Literary Lives: Studies in NineteenthCentury Autobiography, edited by Vincent Newey and Philip Shaw (Aldershot, 1996), which is included here with permission of Scolar/ Ashgate Press.

I should like to thank the Trustees of Dove Cottage, Grasmere, for permission to quote from manuscript inscriptions made in Wordsworth's copy of Shakespeare's Dramatic Works (1790). Figures 1, 2 and 11 are reproduced with permission of the Musée du Louvre, Paris; Figures 5 and 6 by courtesy of Dove Cottage, the Wordsworth Trust, Grasmere; and Figure 10 with permission of the British Museum.

K. H. 